\title{
Sources of Biomass Feedstock Variability and the Potential Impact on Biofuels Production
}

\author{
C. Luke Williams ${ }^{1}$ (D) Tyler L. Westover ${ }^{1} \cdot$ Rachel M. Emerson $^{1}$. \\ Jaya Shankar Tumuluru ${ }^{1}$. Chenlin $\mathrm{Li}^{1}$
}

Published online: 23 November 2015

(C) The Author(s) 2015. This article is published with open access at Springerlink.com

\begin{abstract}
Terrestrial lignocellulosic biomass has the potential to be a carbon neutral and domestic source of fuels and chemicals. However, the innate variability of biomass resources, such as herbaceous and woody materials, and the inconsistency within a single resource due to disparate growth and harvesting conditions, presents challenges for downstream processes which often require materials that are physically and chemically consistent. Intrinsic biomass characteristics, including moisture content, carbohydrate and ash compositions, bulk density, and particle size/shape distributions are highly variable and can impact the economics of transforming biomass into value-added products. For instance, ash content increases by an order of magnitude between woody and herbaceous feedstocks (from $\sim 0.5$ to $5 \%$, respectively) while lignin content drops by a factor of two (from $\sim 30$ to $15 \%$, respectively). This increase in ash and reduction in lignin leads to biofuel conversion consequences, such as reduced pyrolysis oil yields for herbaceous products as compared to woody material. In this review, the sources of variability for key biomass characteristics are presented for multiple types of biomass. Additionally, this review investigates the major impacts of the variability in biomass composition on four conversion processes: fermentation, hydrothermal liquefaction, pyrolysis, and direct combustion. Finally, future research processes aimed at reducing the detrimental
\end{abstract}

Electronic supplementary material The online version of this article (doi:10.1007/s12155-015-9694-y) contains supplementary material, which is available to authorized users.

\section{Luke Williams}

luke.williams@inl.gov

1 Biofuels and Renewable Energy Technology Department, Idaho National Laboratory, Idaho Falls, ID, USA impacts of biomass variability on conversion to fuels and chemicals are proposed.

(C) 2015 Battelle Energy Alliance, LLC, contract manager for Idaho National Laboratory.

Keywords Biomass · Composition · Variability · Conversion · Biochemical · Thermochemical

\section{Introduction}

Biomass is poised to make significant contributions to the domestic and carbon neutral production of fuels and chemicals. According to the "Billion-Ton" study [1] and its update [2] by the United States Department of Energy (USDOE) and United States Department of Agriculture (USDA), biomass has the potential to sustainably supply one third of the nation's petroleum consumption. In fact, enzymatic conversion of lignocellulosic material to fermentable sugars for fuel ethanol is becoming more economically viable [3] with companies such as POET [4], Abengoa [5], and DuPont [6] playing leading roles in the developing ethanol fuel market. However, meeting the US congressional mandate to produce 36 billion gallons of biofuels per year by 2022 will require use of additional biomass resources, including energy crops, forest residues, and other wastes. Figure 1 shows projected terrestrial biomass resource supply curves in the USA in 2022 as farmgate prices increase from $\$ 20$ to $\$ 200$ per dry ton. The average supply for all feedstocks as a function of price is also included and is less than the nominal price for any single feedstock. It is important to note that woody residues dominate the feedstock supply while the price is less than approximately $\$ 50 /$ dry ton. However, as the price rises above $\$ 50 /$ dry ton, the projected quantities of available corn stover, switchgrass, and conventional wood (wood products in 


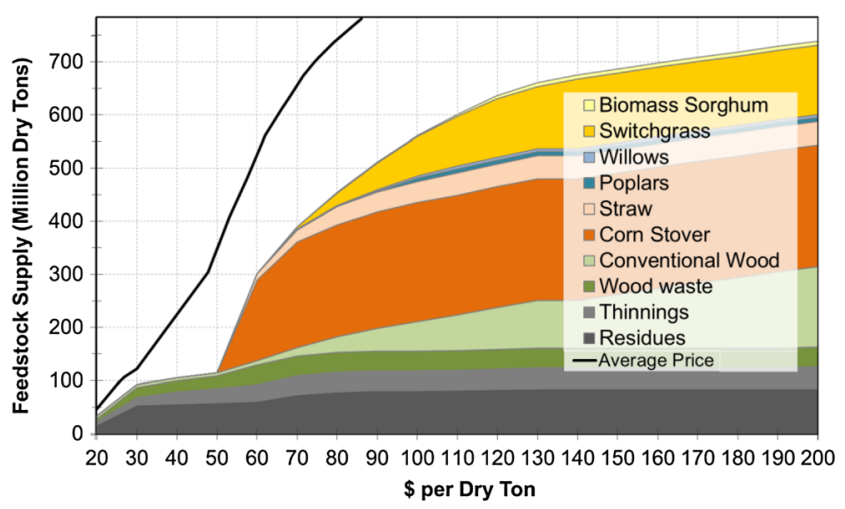

Fig. 1 Biomass supply projections for feedstock prices between $\$ 20$ and $\$ 200 /$ dry ton in 2022. Adapted from [7]

harvest today) increase dramatically and quickly dominate the supply. These projections demonstrate that there will likely be strong cost incentives for biorefineries to combine multiple disparate feedstocks in order to minimize resource cost while increasing feedstock volume to take advantage of economies of scale. Besides feedstock farmgate costs, biorefineries will likely have other important financial reasons to accept multiple feedstocks, including risk reduction through feedstock diversification, reduced storage costs through sourcing materials that can be harvested at different times throughout the year, and reduced transportation costs through taking full advantage of all available local resources.

Once the biomass has been collected, the most economical process for conversion to fuels, chemicals, or energy needs to be selected. Figure 2 depicts a generalized scheme of the primary processing steps for four key conversion pathways: fermentation, hydrothermal liquefaction (HTL), pyrolysis, and combustion/co-firing. The chemical and physical properties of the biomass feedstock have a significant impact on each of the processing steps during these conversion processes. This review briefly summarizes the primary impacts that feedstock properties have on major conversion options. The differences among the available feedstocks and the conversion options offer both opportunities for potential synergies as well as new challenges. For example, the ethanol production model being developed commercially in the Midwest uses almost exclusively corn stover and does not directly transfer to other locations that have different mixtures of biomass resources. In particular, the Northeast and Northwest regions of the USA have much greater woody biomass resources, including residues from the pulp and paper industry as well as other forest harvesting activities. These and other lignin-rich waste products are not well suited for fermentation but are amenable for thermochemical conversion or combustion. As illustrated in Fig. 1, as demand for biomass feedstocks increases, new resources become available, which may dramatically change conversion process parameters. For example, 15 million acres of southern pine plantations could supply 100 million dry tons of clean wood every year, and the costs of those supply systems are decreasing [8]. The mixture of clean pulpwood and less pure forest residues will impact the target conversion processes. Increasing the availability of information describing the effects that physical and chemical properties of different types and fractions of biomass feedstocks have on the performance of a variety of conversion technologies will provide many benefits. For instance, this information will open opportunities to select and tune conversion technologies to further optimize yields while also achieving other environmental and societal benefits, such as increased global sustainability and economic prosperity [9-12].

Another important consideration is that logistics models predict local supplies of biomass for a well-detailed model predicting product output from biomass input. An understanding of how preprocessing operations and natural variability effect physical and chemical properties and how those altered properties improve conversion to energy and fuels is key to developing optimized and sustainable production of renewable fuels, chemicals, and other bio-based products. Tables 1 and 2 summarize key effects of biomass physical and chemical properties, respectively, on the four conversion processes presented in Fig. 2.

Physical and chemical properties have direct impact on conversion performance and also indirect impact through their effects on other properties and processes. For example, moisture content not only directly impacts conversion performance but also impacts dry grinding performance and final particle size distributions which indirectly affect conversion process
Fig. 2 General process for the production of fuels and chemicals through four major conversion pathways: fermentation, hydrothermal liquefaction, pyrolysis, and combustion/cofiring

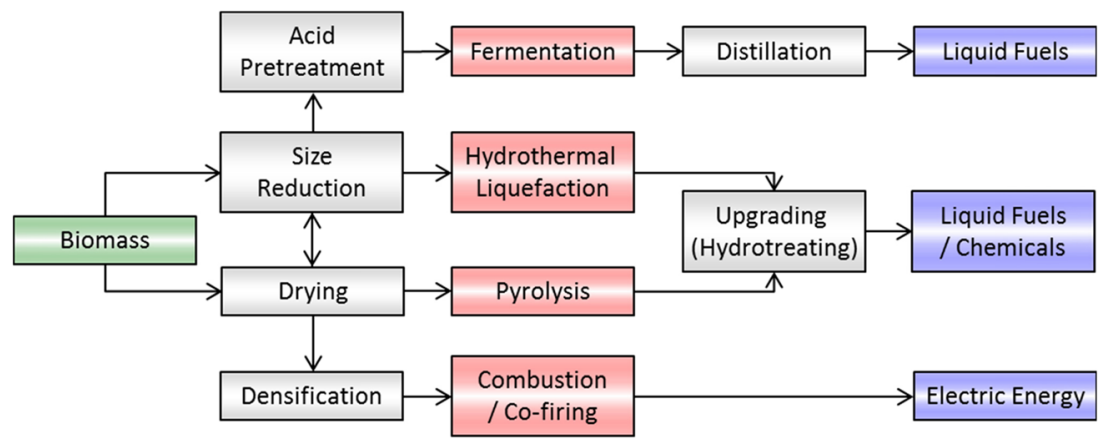


Table 1 Impacts of biomass physical properties on four primary conversion pathways

\begin{tabular}{|c|c|c|}
\hline Property & Conversion process & Impacts \\
\hline \multirow[t]{5}{*}{$\begin{array}{l}\text { Moisture content/ } \\
\text { hygro-scopicity }\end{array}$} & General comments & $\begin{array}{l}\text { Likely, the single most problematic biomass property affecting feedstock supply and biorefining } \\
\text { operations [13]. Moisture often increases transportation costs, and moisture above } 10 \% \text { reduces } \\
\text { calorific value in thermochemical conversion process [14]. Moisture above } 20 \% \text { is generally } \\
\text { recognized to cause dry matter loss in aerobic storage [15]; while moisture in the } 20-40 \% \text { range } \\
\text { causes increased cohesion for poor feeding and handling properties. Moisture also increases dry } \\
\text { grinding energy requirements and affects final particle size distributions with dry feeds having } \\
\text { more fine particles. }\end{array}$ \\
\hline & Fermentation & $\begin{array}{l}\text { Heating rate during steam pretreatment increases with decreasing moisture content and chip size in } \\
\text { the fiber direction }(3.2 \mathrm{~mm})[16] .\end{array}$ \\
\hline & HTL & $\begin{array}{l}\text { Generally slurries with }<20 \% \text { solids loading are required. Higher initial moisture content reduces } \\
\text { hydration time [17]. } \\
\text { Intermediate oils from HTL have lower moisture content and are less hydrophilic than } \\
\text { intermediates from fast pyrolysis [18]. }\end{array}$ \\
\hline & Pyrolysis & $\begin{array}{l}\text { Biomass should be dried to less than } 10 \% \text { water content as additional water in the bio-oil affects } \\
\text { stability, viscosity, } \mathrm{pH} \text {, and other properties [19] including reduced heating rate and moisture in } \\
\text { product [20]. }\end{array}$ \\
\hline & Direct combustion & Moisture present in biomass causes low thermal efficiency due to evaporation [21, 22]. \\
\hline \multirow[t]{5}{*}{$\begin{array}{l}\text { Particle morphology/ } \\
\text { grindability }\end{array}$} & General comments & $\begin{array}{l}\text { Practically, all conversion methods require size reduction. Increasing particle size above } \approx 3 \mathrm{~mm} \text { is } \\
\text { generally associated with poor feeding and handling properties. Sizes below } \approx 1 \mathrm{~mm} \text { with high } \\
\text { moisture content are prone to caking. Thermochemical processes become increasingly sensitive } \\
\text { to particle size as reaction rates increase and residence times decrease. Biochemical conversion } \\
\text { processes are generally more tolerant of larger particles, with size and shape requirements set } \\
\text { primarily by the engineered systems }[23,24] \text {. }\end{array}$ \\
\hline & Fermentation & $\begin{array}{l}\text { Sizes of } 1-3 \mathrm{~mm} \text { are needed for dilute acid pretreatments but chips can be used for processes like } \\
\text { steam explosion [25]. Reducing particle size from } 600 \text { to } 60 \mu \mathrm{m} \text { for sweet sorghum can increase } \\
\text { ethanol yields by a factor of two for solid substrate fermentation (SSF) [26]. }\end{array}$ \\
\hline & HTL & $\begin{array}{l}\text { Particle size has a direct correlation to pumpability and pressure control }[27,28] . \\
\text { Particle size has a minimal effect on heat transfer in liquid water but smaller particles will show a } \\
\text { slight decrease in solid residue }(14-7 \%) \text { for mixtures of perennial grasses at } 374{ }^{\circ} \mathrm{C} \text { and } \\
22.1 \mathrm{MPa}[29] .\end{array}$ \\
\hline & Pyrolysis & $\begin{array}{l}\text { Char yield increases for many biomass types as size increases larger than } 0.5 \mathrm{~mm} \text { due to reduced } \\
\text { heating rates [30]. }\end{array}$ \\
\hline & Direct combustion & $\begin{array}{l}\text { Size must be sufficiently small that complete combustion occurs; however, excessive fines results } \\
\text { in more than optimum particle volatility. The optimum size varies for different biomass types } \\
\text { and is approximately } 6 \mathrm{~mm} \text { for straw, } 4 \mathrm{~mm} \text { for miscanthus, and } 2-4 \mathrm{~mm} \text { for wood [31]. }\end{array}$ \\
\hline Bulk density & General comments & $\begin{array}{l}\text { Low bulk density increases transportation and handling costs as well as aggravates performance in } \\
\text { gravity-based feeding and handling systems. }\end{array}$ \\
\hline $\begin{array}{l}\text { Compressibility/ } \\
\text { elasticity }\end{array}$ & General comments & $\begin{array}{l}\text { Causes increased feeding and handling difficulty because elastic recovery in feed systems affects } \\
\text { compressive stresses and material shear strengths at constricted flow points, such as hopper } \\
\text { openings. }\end{array}$ \\
\hline Microstructure & General comments & $\begin{array}{l}\text { Open microstructure results in increased access and surface area for biochemical conversion. } \\
\text { Rough microstructure results in high inter-particle friction forces with corresponding high shear } \\
\text { strengths and poor feeding behavior. Microstructure also affects adhesion to container walls, } \\
\text { reducing cleanout, and live storage volume as well as potentially resulting in spoilage. }\end{array}$ \\
\hline
\end{tabular}

efficiency. In straws and stover, decreasing moisture content from 12 to $7 \%$ can decrease grinding energy by approximately $5 \mathrm{kWh} / \mathrm{t}$ for particle sizes $1.6 \mathrm{~mm}$ and smaller [44]. Decreasing moisture content by a factor of two can reduce grinding energy by a factor of four for particle sizes between 3 and $6 \mathrm{~mm}$ for canola [45]. The harvest season can significantly impact moisture content of biomass resources. Moisture content generally decreases for late fall harvests, reducing required drying energy for pyrolysis or combustion processes but having little effect on hydrothermal liquefaction or fermentation processes [27, 41]. Infield drying for 90 days decreases moisture content of pine trees, even in humid southern US climates, where reductions to 30 and $40 \%$ moisture content have been reported for summer and winter conditions, respectively [8]. In addition to moisture content and particle morphology, variation in ash content, volatiles, and structural carbohydrate to lignin ratios effect a wide range of parameters from specific grinding energy and flowability to product distributions from pyrolysis and fermentation (Tables 1 and 2) [13]. 
Table 2 Impacts of biomass chemical properties on four major conversion pathways

\begin{tabular}{|c|c|c|}
\hline Property & Conversion process & Impacts \\
\hline \multirow[t]{5}{*}{ Ash content } & General comments & $\begin{array}{l}\text { Ash content has been shown to negatively affect most conversion processes. There have been many efforts } \\
\text { to reduce ash in biomass. Hydrothermal pretreatment with sodium citrate at a level of } 0.25 \mathrm{~g} / \mathrm{g} \text { biomass } \\
\text { can reduce structural ash content by } 77 \% \text { [32]. Air classification can selectively remove large portions of } \\
\text { ash }(41 \%) \text { while only removing a relatively small quantity of organic biomass }(6.7 \%) \text { [33]. }\end{array}$ \\
\hline & Fermentation & $\begin{array}{l}\text { Ash content in soil can reduce the effectiveness of dilute acid pretreatment and lower digestible sugars yield } \\
\text { [34]. }\end{array}$ \\
\hline & HTL & High ash content can increase the amount of solid residue formed [35]. \\
\hline & Pyrolysis & $\begin{array}{l}\text { Lower ash can increase oil yields by } 1-5 \% \text { for each } 1 \% \text { of ash removed from native biomass }[20,36] \text {. } \\
\text { Can cause reactor fouling, the change in ash content from wood }(\sim 1 \% \text { ash) to straw }(5-10 \% \text { ash) can } \\
\text { change the deposition rate from } 10 \text { to } 0.1 \mathrm{~g} \text { deposit } / \mathrm{kg} \text { fuel [14]. }\end{array}$ \\
\hline & Direct combustion & $\begin{array}{l}\text { Causes heat exchanger fouling and reduces the heating value of the fuel by } 0.16 \mathrm{MJ} / \mathrm{kg} \text { for each } 1 \% \\
\text { reduction in ash for rice straw [37]. }\end{array}$ \\
\hline \multirow[t]{5}{*}{ Volatiles } & General comments & Generally removing volatiles content decreases acidity and improves energy density. \\
\hline & Fermentation & $\begin{array}{l}\text { Volatiles derived from hemicellulose such as acetic acid and furan can inhibit fermentation [38] while } \\
\text { compounds like acetic acid and phenolics can reduce fermentation efficiency by } 40 \% \text { [39]. }\end{array}$ \\
\hline & HTL & $\begin{array}{l}\text { About } 50 \% \text { of the oxygen rich volatiles can be reduced, leading to greater energy density of the solid char } \\
\text { product from pine sawdust hydrothermal preprocessing [40]. }\end{array}$ \\
\hline & Pyrolysis & Increased volatiles increases fuel acidity and affect upgradeability and stability [20]. \\
\hline & Direct ombustion & $\begin{array}{l}\text { Increased volatile content will cause biomass to burn faster since about } 75 \% \text { of the volatiles are released } \\
\text { and burned in the early stages of pyrolysis [21]. }\end{array}$ \\
\hline \multirow[t]{5}{*}{ Lignin } & General comments & $\begin{array}{l}\text { Lignin can benefit thermochemical conversion processes by increasing oil yields and improving energy } \\
\text { density but is a waste product for biochemical fermentative processes. }\end{array}$ \\
\hline & Fermentation & $\begin{array}{l}\text { Lignin degradation products from biomass pretreatment can inhibit ethanol production [38]. } \\
\text { Lignin can block enzyme access to the cellulose and reduce ethanol yields [41]. }\end{array}$ \\
\hline & HTL & $\begin{array}{l}\text { Differences in lignin content can affect the phenolic components in the resulting oil product. It was shown } \\
\text { that the phenolic composition increased in the oil of lignin rich cypress ( } 34.4 \% \text { lignin) as compared to } \\
\text { cherry }(12.5 \% \text { lignin) [42]. }\end{array}$ \\
\hline & Pyrolysis & $\begin{array}{l}\text { Increasing lignin can improve oil yields and increase the average molecular weight of the bio-oil by about } \\
100 \text { Daltons (Da) as lignin content increases from } 5 \text { to } 15 \%[36] \text {. }\end{array}$ \\
\hline & Direct combustion & $\begin{array}{l}\text { Lignin has a greater heating value than the cellulosic fraction of biomass at } 25 \mathrm{~kJ} / \mathrm{g} \text { as compared to } 18.6 \mathrm{~kJ} / \mathrm{g} \\
{[21,22] \text {. }} \\
\text { Much of the char is formed by lignin. The remaining lignin char can amount to } 55 \mathrm{wt} \% \text { of the original mass } \\
\text { as opposed to } 20 \text { and } 8 \% \text { for hemicellulose and cellulose, respectively [ } 43] \text {. }\end{array}$ \\
\hline
\end{tabular}

\section{Biomass Composition}

Understanding biomass chemical composition and how each component behaves in the selected conversion processes is fundamental to addressing the issues of variability. The chemical properties of lignocellulosic materials, commonly referred to as biomass, are primarily controlled by five key components: cellulose, hemicellulose, lignin, extractives/volatiles, and ash. Cellulose is a crystalline polysaccharide composed of glucose monomers held together by $\beta(1 \rightarrow 4)$ linkages that are resistant to hydrolysis. Hemicellulose is an amorphous heteropolymer comprised of various carbohydrate monomers, including but not limited to xylose, mannose, and glucose. Because of its chemical structure, hemicellulose is much more susceptible to hydrolysis than cellulose. Lignin, the third major chemical component of biomass, is a complex array of aromatic alcohols that are heavily intertwined within the biomass structure and help provide rigidity to the plant as a whole.
Lignin can be beneficial for thermochemical conversion processes increasing oil yield and molecular weight [36]. However, for fermentative processes, it has a detrimental effect in that phenolic lignin degradation products can inhibit ethanol production [38]. Extractives are made up of water-soluble components, such as non-structural sugars and proteins, and ethanol soluble components, such as chlorophyll and waxes. Volatiles from hemicellulose reduce fermentation efficiency in biochemical processes [39] and can increase the acidic nature of oil produced from thermochemical processes, which is associated with increase of viscosity during bio-oil storage [20]. Inorganic material, often referred to as ash, can be intrinsic to the biomass structure, such as calcium and potassium ions, or primarily anthropogenic, such as silica acquired during harvest. Ash content and composition can have detrimental effects on thermochemical processes by lowering oil yields and fouling reactors [21] while only slightly reducing the effectiveness of dilute acid pretreatment for fermentation [34]. 
Variations in the distributions of these five components can be substantial across types of biomass, including woody, herbaceous, and algal. Additionally, there is a significant variation among specimens of the same biomass type and between various tissue fractions of the same specimen (i.e., tree leaves have different structural components than the wood). This review compiles information on broad chemical compositions of different biomass types and tissue fractions while referring readers to additional sources for detailed biomass chemical compositions. More detailed compositions can be found for principal biomass components [46], chemical composition of the ash [47], and bulk constituents like cellulose, hemicellulose, lignin, and extractives [48].

In general, herbaceous feedstocks, in addition to having higher ash content, exhibit more variability in their composition than woody biomass [49]. However, not all characterization methods report identical biomass composition values, resulting in apparent biomass variability that is dependent upon the different methods used to measure the desired properties.

\section{Defining the Extent of Biomass Variability}

Biomass variability is a result of many different factors including component analysis methods, feedstock types, environmental factors, harvesting practices, storage conditions, and preprocessing techniques. Some of these factors can be controlled through standardization practices while other factors can be difficult to control. The influence of environmental conditions on biomass composition is particularly difficult to control because they are subject to variations in weather, including total supply and timing of water, daily and seasonal temperature swings, and variations in local soil conditions (e.g., clay, sand, rock, nutrient content, and $\mathrm{pH}$ ) [50]. In addition, different conversion technologies place varying levels of emphasis on diverse quality metrics, which further complicating inherent biomass variability [13]. As densification technologies continue to improve and as national and global biofuels industries emerge, biomass resources will be shipped greater distances, potentially increasing the variability of biomass received at biorefineries as well as offering new opportunities to reduce variability through wider supply and blending. However, issues of low bulk mass and energy densities must be addressed to keep transportation costs economical $[51,52]$. It is important to understand all potential sources of variability in order to expand the current feedstock supply and to mitigate factors that will cause fluctuations in product quality.

\section{Variability within Biomass Analysis}

The quantitative characterization of biomass has a long and complicated evolution that includes many analytical techniques. Different methods that measure the same parameter, as well as variations in process execution, lead to variability in reported analytical values. For example, measurements of biomass fuel properties for thermochemical conversion are currently based on ASTM methods for ultimate and proximate analysis of coal and coke [53, 54]; however, through the use of these methods, the variation within biomass is typically greater than that of coal [46]. For biochemical conversion processes, methods from the Technical Association of the Pulp and Paper Industry (TAPPI) for analysis of carbohydrates and lignin from pulps and pulp wood (T-222, T-249) have been used and adapted. The National Renewable Energy Lab (NREL) has adapted these methods and continues to develop and provide laboratory analytical procedures (LAPs) that are specific to biofuels [55, 56]. NREL's adaptations of these methods has included the analysis of structural components in biomass that focus on using high-performance liquid chromatography (HPLC) and UV-vis spectroscopy to obtain information on cellulose, hemicellulose, and lignin content [57]. However, even small changes to the analytical methods can have a strong effect on the uncertainties of empirical methods [58]. The full details of these methods are beyond the scope of this review, but a collection of ASTM and other standard methods for various types of biomass analysis can be found in the Supporting Information (Tables S1, $\mathrm{S} 2$ and S3).

An additional source of analytical variability is the development of predictive models from spectroscopic data to analyze biomass physical and chemical properties. Historically, assessing the variability in biomass composition has been impeded by the large time required for the analyses. For example, obtaining structural carbohydrate information for a large number of samples can take weeks. Highthroughput methods utilizing near-infrared spectroscopy (NIR) combined with chemometrics have been developed to characterize large numbers of samples for major biomass components, such as glucan, xylan, solubles, and lignin $[55,56]$. Even more promising, these models can be continuously updated and expanded to increase predictive utility as more biomass samples are added. Recently, Paulsen et al. have obtained in situ biomass structural information using spatiotemporally resolved diffuse reflectance spectroscopy in a reactive fast pyrolysis system for woody feedstocks [59]. This new technique could allow for the monitoring of lumped carbohydrate content during pyrolysis. In the future, these new rapid screening analysis techniques, such as NIR spectroscopy, will likely help to minimize the effects of variability by providing detailed in-line chemical characterization if models are based on standard chemical measurement techniques, such as NREL's LAPs. This rapid in-line analysis offers additional opportunities to control feed stream composition by blending biomass real-time during feedstock preprocessing. 


\section{Chemical Composition Variability between Different Types of Biomass}

Kenney et al. have thoroughly reviewed many of the sources of variability within biomass [13]. In order to compile agronomic and chemical data on biomass feedstocks from across the nation, the US DOE maintains a publically available database at Idaho National Laboratory (INL) that contains characterization information and statistical tools to assess the variability of important bioenergy feedstocks $[60,61]$. In order to utilize multiple feedstocks for a specific conversion process, variation in chemical properties between different feedstocks must be considered. Table 3, which utilizes information from the INL database and a compilation of chemical data from previous reviews, shows multiple structural analyses on a variety of biomass samples. Pine (a softwood) has the highest lignin content, followed by hybrid poplar (a hardwood), while herbaceous materials have the least lignin. Because lignin has high energy content, the heating values of the materials follows the same order as the lignin. Compositional data like this is crucial to gaining an understanding of feedstock properties prior to selecting a processing or conversion technology. For instance, using the knowledge that softwoods have higher lignin content could make them more suited for combustion in energy applications.

Individual feedstocks vary significantly in their composition (Table 3). This problem becomes magnified when considering other, more diverse, bioenergy feedstocks. A prime example of this is mixed natural rangeland grasses, which may be used for fermentation processes. These grasses preserve natural habitat and typically require less maintenance than traditional energy crops; however, their naturally high variability can lead to reduced and highly variable product yields. Species variety in herbaceous crops grown on conservation grassland has a detrimental effect on the ethanol yield per unit area as plant species diversity increases. Ethanol yields per unit land increased drastically with increased targeted coverage of $\mathrm{C}_{4}$ prairie grass energy crops, like switchgrass, which sequester more carbon than typical $\mathrm{C}_{3}$ conservation grassland varieties [63].

While different types of biomass can exhibit distinct composition differences, certain aspects of the biomass composition can be mitigated or enhanced by mechanical or chemical manipulation, such as anatomical fractionation. The chemical differences that can occur between anatomical fractions for woody biomass and corn stover are illustrated in Table 4.
Table 3 Representative structural composition of various feedstocks

\begin{tabular}{lllll}
\hline Parameter & Pine $^{\mathrm{a}}$ & Hybrid Poplar & Switchgrass & Corn stover \\
\hline Proximate analysis (wt\%) & $n=27$ & $n=19$ & $n=102$ & $n=171$ \\
Ash & $0.6(0.3)$ & $1.2(0.1)$ & $6.8(4.0)$ & $7.6(4.1)$ \\
Volatile matter & $76.4(6.9)$ & $84.0(0.6)$ & $74.9(6.3)$ & $75.4(4.8)$ \\
Fixed carbon & $17.9(3.5)$ & $14.8(0.6)$ & $14.4(2.2)$ & $14.8(1.6)$ \\
Ultimate analysis (wt\%) & $n=26$ & $n=19$ & $n=102$ & $n=170$ \\
Carbon & $49.4(1.7)$ & $50.0(0.2)$ & $45.5(3.8)$ & $44.4(3.6)$ \\
Hydrogen & $6.4(0.2)$ & $5.9(0.1)$ & $5.9(0.3)$ & $5.9(0.4)$ \\
Oxygen (by diff.) & $43.5(1.6)$ & $42.5(0.3)$ & $41.6(2.4)$ & $42.8(3.6)$ \\
Nitrogen & $0.2(0.1)$ & $0.3(0.1)$ & $0.8(0.7)$ & $0.6(0.2)$ \\
Sulfur & $0.0(0.0)$ & $0.0(0.0)$ & $0.1(0.0)$ & $0.1(0.0)$ \\
Chlorine (PPM) & $42(36)^{\mathrm{c}}$ & $19^{\mathrm{d}}$ & $1400^{\mathrm{d}}$ & $8500(6200)^{\mathrm{e}}$ \\
Higher heating value (MJ/kg, dry basis) & $19.6(0.7)$ & $20.2(0.3)$ & $17.0(1.0)$ & $17.3(0.7)$ \\
Average structural components (dry basis) & $n=9$ & $n=5$ & $n=30$ & $n=23$ \\
Cellulose & $30.9(5.5)$ & $45.7(3.1)$ & $34.4(5.0)$ & $34.6(3.1)$ \\
Hemicellulose & $19.3(1.5)$ & $19.1(2.1)$ & $25.7(4.9)$ & $24.6(4.1)$ \\
Lignin & $29.0(2.1)$ & $24.9(2.6)$ & $16.1(2.3)$ & $13.9(1.7)$ \\
Extractives & $7.8(2.4)$ & $5.5(4.0)$ & $12.3(3.5)$ & $14.3(5.4)$ \\
\hline
\end{tabular}

Each parameter category has the number of samples included in the average $(n)$. Numbers in parenthesis indicate one standard deviation. Source: INL library [60], Vassilev 2012 [48], Towler 2004 [62], Jenkins 1998 [21], Kirubakaran 2009 [43], Lynd 1999 [25]

${ }^{a}$ Some sources included other softwood values (other than pine) in averages

${ }^{\mathrm{b}}$ Some sources included other hardwood values (other than shrub willow) in averages

${ }^{\mathrm{c}} n=2$

${ }^{\mathrm{d}} n=1$

${ }^{\mathrm{e}} n=9$ 
Table 4 Woody biomass and corn stover compositional variation by anatomical fraction

\begin{tabular}{lllll}
\hline Structural component & Cellulose & Hemicellulose & Lignin & Extractives \\
\hline Woody biomass (wt\%-daf) ${ }^{\mathrm{a}}$ & & & & \\
$\quad$ Whole tree & 51.2 & 23.4 & 25.4 & 3.0 \\
Bark & 22.0 & 47.0 & 31.0 & 3.3 \\
Twigs & 15.4 & 62.3 & 22.3 & 1.6 \\
Leaves & 26.5 & 47.2 & 26.3 & 3.7 \\
Corn $(w t \%-d b)$ & & & \\
Corn cobs & 35.92 & 30.7 & 16.44 & 5.89 \\
Corn leaves & 34.33 & 22.77 & 13.99 & 10.54 \\
Corn husk & 37.73 & 31.18 & 10.52 & 5.80 \\
Corn internodes & 40.21 & 20.03 & 17.24 & 12.29 \\
\hline
\end{tabular}

$d a f$ dry ash free, $d b$ dry basis

${ }^{a}$ [48] Vassilev et al.

${ }^{\mathrm{b}}$ [60] INL Library

Woody biomass contains most of the cellulose in the heartwood (represented by Whole Tree), while the bark contains a greater percent lignin, and the leaves contain a higher concentration of extractives. Corn stover, on the other hand, has the majority of the extractives in the leaves and internodes (the links between different stalk segments). Differences in composition with anatomical fractions can also be seen in other biomass types. For example, different fractions within wheat stover can exhibit an almost $10 \%$ difference in glucan content with some fractions being much more susceptible to chemical saccharification [64]. Increased susceptibility to saccharification for different plant fragments can also be seen in corn stover in which the cobs, husks, and leaves exhibit better response than the stocks to simultaneous saccharification and fermentation (SSF) despite having similar glucan levels [65]. Careful selection of the anatomical fraction processed could allow for greater control over ash and compositional content in a conversion facility feed stream. Additionally, feed stream or anatomical fractionation can improve the economics of a process by separating high value components. This is exemplified by the use of distiller dried grains and solubles (DDGS) in ethanol production for high protein animal feed as opposed to turning the DDGS into fuels or chemicals $[66,67]$.

\section{Variability Due to Local Agronomic Conditions}

Geographic location affects feedstock characteristics through variations in local agronomic conditions. Templeton et al. [56] investigated corn stover composition over much of the US Midwest. Harvest year and geographic location has a greater impact on the structural content of corn stover than does the genetic variety $[56,68]$. The variations in biomass composition, especially for genetically similar biomass, can often be correlated to differences in water and temperature conditions [69]. A particularly problematic source of variability is drought, because it cannot be easily controlled or mitigated $[50,70,71]$. Drought can increase the water-soluble carbohydrate content of plants while the overall mass yield decreases [70-73]. Drought drastically decreases the theoretical ethanol yield (TEY) of mixed perennial grasses and Miscanthus $\times$ giganteus in a fermentative process by increasing extractives and decreasing structural sugars, in addition to reducing the quantity of biomass produced per unit land [50]. Overall, drought reduced TEY by $26-59 \%$ per hectare for mixed perennial grasses and Miscanthus $\times$ giganteus through a combination of overall dry matter loss and a reduced fraction of structural carbohydrates [50].

\section{Variability Due to Harvest Conditions}

Harvest conditions, including equipment type, process, season, and weather, are another substantial source of biomass variability. Ash, structural carbohydrates, and moisture are due to such harvesting conditions [13]. Delaying harvest for corn stover results in drying and decreased structural carbohydrates without significantly lowering the overall energy content [74], which would benefit thermochemical conversion processes, such as co-firing and pyrolysis, because of the lower moisture content. Ideally, harvest time is optimized to maximize sequestered carbon content while reducing ash content [69]. Table 5 summarizes variation in ash content of switchgrass collected with commercial harvesting equipment for different harvest years, seasons, and locations. Harvests within 2007-2010 collected in Minnesota exhibited the highest mean ash content $(9.31 \%)$, while the spring harvests from 20012005 collected in Pennsylvania exhibited the lowest mean ash content $(2.26 \%)$. Over the same time periods, the mean ash contents of the spring harvests were approximately $1 \%$ lower than that of the fall harvests due to winter senescence. Adler et al. [75] investigated the benefit of delaying harvest to 
Table 5 Ash content variation in switchgrass by harvest season and year

\begin{tabular}{ll}
\hline Biomass type & Mean total ash \\
\hline Fall (2007-2010) [62] & 9.31 \\
Spring (2007-2010) [62] & 8.67 \\
Fall (2001-2005) [75] & 3.46 \\
Spring (2001-2005) [75] & 2.26 \\
$(2000)[68]$ & 5.2 \\
$(1999)[68]$ & 7.2 \\
$(1998)[68]$ & 6.3 \\
\hline
\end{tabular}

Source: [62] INL Library, [75] Adler et al., [68] Lemus et al. (three cultivars at two locations)

reduce ash content against biomass senescence and concluded that the economics of a delayed harvest would depend on the intended conversion process. If the biomass is going to a combustion process, the reduced ash may be worth the loss in carbon as the biomass degrades but the same may not be true for a fermentative process. Even when harvests of multiple cultivars and locations are considered, year-to-year variations can be still be significant as indicated by a $2 \%$ decrease in mean ash content between samples harvested in 2000 compared to 1999 [68].

Delaying the harvest time of Miscanthus, a potential herbaceous bioenergy crop, from late fall to early spring drastically decreases ash content by about $30 \%$ while decreasing biomass yields by about $13 \%$ [76]. As Miscanthus crops experience partial decomposition during winter, there is a loss of organic carbon but also a reduction in the $\mathrm{SO}_{2}$ output as $\mathrm{N}$, $\mathrm{Cl}$, and $\mathrm{S}$ are reduced by delaying harvest [77]. Cool season grasses, typical of northern climates, senesce earlier than warm season grasses like switchgrass and Miscanthus. This early senescence facilitates earlier harvests, but cool season grasses vary more widely in composition and tend to have greater ash content [78]. In a recent study on the potential for mixed rangeland grasses as fermentation feedstocks [79], biomass yield was the primary determinant on theoretical ethanol yield while both harvest season and geographic location affected overall biomass yield.

Harvesting operation and equipment are important sources of variation of feedstock properties. Hand harvesting willow woodchips leads to lower ash content than commercial harvest operations [69]. Variation in hand-collected ash and moisture data was small relative to reported data for large-scale harvests of herbaceous crops and agriculture residues which were primarily affected by geographic location and cultivar. Combined hand and commercial harvesting should be performed to assess the quantity of entrained soil collected by commercial harvest systems [69]. Differences in total ash content for corn stover harvested in Kansas due to differences in harvesting equipment were between 11.5 and $28.2 \%$ [80].

\section{Impact of Physical and Compositional Variability on Biochemical and Thermochemical Conversions}

As outlined above, many factors contribute to biomass compositional variability, and this variation can have a significant impact on the conversion of biomass to value-added products. Ideally, these problems could be mitigated through selection of pretreatments, conversion processes, or by blending different types of biomass to diminish detrimental effects, e.g., reduce the effective ash content of herbaceous materials by blending them with woody biomass. The following section covers the basic principles behind the four major conversion processes: fermentation, hydrothermal liquefaction, pyrolysis, and direct combustion with respect to how biomass variability affects each conversion process.

\section{Ethanol Production Through Fermentation}

The production of ethanol from lignocellulosic biomass occurs through two major steps: deconstruction of the cellulose and hemicellulose to fermentable sugars and fermentation of these sugars to ethanol. This conversion process has been evaluated in many informative reviews [3, 41, 81-85] which vary from focusing on pretreatment and enzymatic hydrolysis of lignocellulosic materials [41], to optimization of cellulase enzyme, microorganisms, fermentation processes for improving sugar conversion to ethanol [82], and evaluation of economic aspects and future outlook for fuel ethanol production $[85,86]$.

Physical and chemical characteristics of biomass can affect ethanol yield and process economics. The production of ethanol through microbial fermentation is typically much more dependent on biomass carbohydrate content and less susceptible to ash content. Therefore, fermentation is particularly well suited to herbaceous crops that typically have higher ash contents [87]. However, alkali metal content in soil collected while harvesting biomass can adversely affect the typical acid pretreatment and enzymatic hydrolysis, which releases the fermentable sugars. Soil content of the harvested biomass can directly increase the acid neutralization capacity, and therefore lower the xylan digestibility, of corn stover upon dilute acid pretreatment [34]. Adjusting total carbohydrate content by $1 \%$ of total dry matter can change the minimum ethanol selling price (MESP) by $\$ 0.018 /$ gal [86].

One aspect of biomass variation that could be utilized in ethanol production is the difference between anatomical fractions for a plant like corn stover. Differences in structural carbohydrates with anatomical fraction in corn stover have a significant effect on glucose yield. Glucose concentration after hydrolysis was three times greater in the cobs, leaves, and husks than the stalks [88]. Therefore, anatomical fraction and selective fermentation of the most valuable components 
could increase process efficiency if a good alternative can be found for the stalks.

\section{Hydrothermal Liquefaction}

Hydrothermal treatments involve the reaction of biomass in an aqueous media for the production of either liquids or, in some cases, gases. These reactions are performed over a wide range of temperatures $\left(200-600{ }^{\circ} \mathrm{C}\right)$ and are done at high pressures (5-40 MPa) to keep the water in the liquid or supercritical phase. Reactions from $200-350{ }^{\circ} \mathrm{C}$ are typical for liquid products while temperatures above $400^{\circ} \mathrm{C}$ are suitable for gaseous products. Sub and supercritical water technologies span a wide range of temperatures, feedstocks (model compounds as well as biomass), and final products including both liquid bio-oils and gases [18]. Hydrothermal treatments can target liquid products from a variety of feedstocks [17, 35], including products normally thought of as waste, such as lignin [89].

Liquid reaction media is well suited for utilizing biphasic systems to improve process separations. Luterbacher et al. achieved sugar yields of $65 \%$ from woody biomass and $55 \%$ from switchgrass using a biphasic water $/ \mathrm{CO}_{2}$ system with $\sim 1 \mathrm{~cm}$ particles and $40 \mathrm{wt} \%$ solids [90]. The targeted production of sugars from biomass instead of oils could facilitate the production of high-value chemicals, like renewable plastics, instead of fuels [91]. Production of bio-oils, instead of sugars, through HTL typically gives lower yields than pyrolysis. However, HTL bio-oils tend to have higher quality and save energy because the feedstocks do not require drying prior to conversion [35]. In addition, HTL bio-oils typically have a lower oxygen content than fast pyrolysis oils, which gives them their higher quality, while still having a greater oxygen content than crude oil [18].

As a pretreatment process, mild hydrothermal treatment reduces ash content when used in combination with a sodium citrate chelating agent [32]. This could have potential benefits when processing biomass for further conversion processes that require low ash content. However, the additional energy required to remove water from the chelating process reduces the economic viability of this process for pyrolysis or gasification conversion. Utilizing hydrothermal liquefaction as a conversion process provides at least two advantages: the aqueous reaction media allows for a wide variety of feedstocks, regardless of initial moisture content (even marine biomass with up to $90 \%$ water) and reactions are fairly independent of particle size given the high heat transfer rates in hydrothermal media [17]. These facts make HTL well suited for a diverse array of feedstocks.

\section{Pyrolysis}

Pyrolysis is a thermochemical treatment that increases biomass energy density by removing oxygen through water and volatiles while producing oils that can be upgraded to fuel. Pyrolysis is typically performed at temperatures of 400 $600{ }^{\circ} \mathrm{C}$ [92] and often includes a catalyst [93]. Biomass pyrolysis processes have been extensively reviewed $[19,20$, 93-98].

Pyrolysis processes are particularly well suited for low moisture content woody materials with minimal ash and higher lignin content. For example, lignin content in woody biomass can increase the average molecular weight of pyrolysis oil by $100 \mathrm{Da}$ as the lignin content increases from 5 to $15 \%$ [36]. Raw herbaceous materials are less favorable for pyrolysis conversion because they have lower lignin content compared to wood and much higher ash content. Pyrolysis oil yield decreases by $1-5 \%$ for every $1 \%$ increase in ash [36]. In addition to decreasing oil yields, alkali metals and other inorganics, which are common in fertilizers used on herbaceous crops, can have damaging effects on reactors and reduce catalyst lifetimes [99]. However, the effect of ash on overall pyrolysis and upgrading performance is not fully clear. The effects of ash content ranging from 0.7 to $1.6 \%$ on several feedstocks including pines, poplars, switchgrass, and corn stover in an integrated fast pyrolysis and oil hydrotreating upgrading process was found to be statistically insignificant [100].

\section{Combustion and Co-Firing}

Fire is ingrained in human civilization and has been used for everything from managing agricultural lands to the production of energy for tens of thousands of years and is still highly used in developing countries [101]. In modern developed countries, non-renewable fossil fuels such as oil, coal, and natural gas are the prime energy sources; however, these sources could be depleted within the next $40-50$ years [102]. To reduce the depletion of non-renewable sources and reduce environmental impact, there is movement towards the combustion of renewable biomass and other waste products (like paper and plastics). Demirbas has produced several reviews on the combustion of biomass as a renewable energy source $[22,30,102$, 103]. Additionally, Tumuluru et al. has extensively reviewed torrefaction for transforming raw biomass into a feedstock that is suitable for co-firing applications $[14,104,105]$.

The largest problem associated with the combustion of biomass (as well as waste products) is that biomass has a very low heating value compared to non-renewable fossil fuels, and the increased inorganic species in the biomass can cause boiler fouling and reduce combustion efficiencies $[21,106]$. However, while biomass can increase reactor fouling, it also reduces harmful emissions compared to coal [107]. An additional benefit is that energy produced through biomass combustion can be incorporated directly into the current energy grid without requiring infrastructure changes. 


\section{Minimizing the Impact of Biomass Variability on Conversion Processes}

This article has discussed inherent and introduced biomass variability as well as the downstream effects on the current conversion processes. Due to the loss in efficiency and profit associated with biomass variability, it is important to develop methods that could serve to mitigate these harmful effects and increase conversion efficiency. These methods will likely involve chemical, physical, or thermal pretreatments combined with the development of a uniform format supply system.

\section{Chemical, Physical, and Thermal Pretreatments Methods}

Chemical pretreatments address the issue of biomass variability by providing a potential route for the fractionation of biomass into process streams of constituent components, like cellulosic material and lignin, as well as a way to remove ash. Specific chemical pretreatments include steam, liquid water, acids, bases, ionic liquids [108], organosolv [109], sulfite pretreatment (SPORL) [110, 111], and ammonia fiber explosion (AFEX) [112]. Chelating agents like sodium citrate effectively remove ash from corn stover under mild hydrothermal pretreatment [32]. These chemical pretreatments can be strongly influenced by processing parameters. For instance, particle size and anatomical composition alter the effectiveness of AFEX for corn stover with the larger cobs and stalks being more recalcitrant than the leaves and husk [113]. A greater fundamental understanding of these various pretreatment technologies will enhance their use for particular conversion technologies.

Densification technologies, such as briquetting and pelletization, assure uniformity of physical properties, while having minimal impact on chemical composition [114, 115]. Densification also enables low-cost transportation, increases shelflife for outdoor storage, and improves feeding and handling performance. Dry and wet thermal treatments, such as torrefaction, mild hydrothermal carbonization, and steam explosion can also reduce hygroscopicity, increase grindability and shelf-life, and reduce volatiles and extractives content, including organic acids $[20,104,105,114,116]$.

\section{The Uniform-Format Supply System}

Currently, there are several options to lessen the challenges associated with variation of key biomass attributes, such as constituent ash, structural carbohydrates, and moisture content. These options include selecting regionally adapted cultivars,[117] and tailoring harvest times/techniques for desired outcomes. As mentioned above, the effects of biomass variability can also be actively addressed using chemical, thermal, or biological preprocessing steps to transform raw biomass into commodity feedstocks with uniform physical properties
[118]. A uniform-format supply system that enables different types and fractions of biomass to be exchanged as commodities would facilitate formulating and blending to achieve quality specifications $[116,119]$. Preprocessing steps that separate, formulate, and format feedstocks could be performed at strategically distributed facilities (depots), and then densified commodities can be shipped to central biorefineries or other end-use locations. An additional advantage of this model, which follows the current world-wide grain commodity system, is that it reduces risks associated with feedstock supply, including fluctuations due to seasonal changes, disease, and natural disasters [118, 120, 121].

Future research should seek to balance efforts which develop low-cost feedstock preprocessing systems that prepare raw biomass for local conversion methods with more advanced pretreatments that transform materials into commodities that can be exchanged in global biofuels and bio-based products markets. For instance, herbaceous materials (such as corn stover) have high ash content ( $>5 \%)$ and more fermentable sugars, so enzymatic hydrolysis and fermentation are natural conversion pathways. In regions where these plants grow in high densities, such as the Midwest and Southeast, minimal preprocessing is adequate to prepare the biomass for conversion. Similarly, short-rotation softwoods and hardwoods can be grown in high densities in the Southeast and Northwest and also show promise in the Midwest and Northeast. These feedstocks can be prepared for fast pyrolysis or hydrothermal liquefaction with little preprocessing because they have inherent low ash content $(<0.5 \%)$. In regions where diverse biomass types are cultivated or where there is lower feedstock production, more advanced preprocessing operations, especially densification, are needed so that the biomass can be collected into commodity markets. Placing greater focus on the production of chemicals and other high-value products, such as vanillin and other aromatic aldehydes from waste lignin, would also serve to increase the cost competitiveness of bio-based industries, including biofuels. In many cases, the same processes that enable high value co-products could also reduce feedstock variability by separating feed streams according to chemical composition.

\section{Conclusions}

Innate and introduced variability between different biomass resources impedes the utilization of biomass as a carbon neutral and domestic source for fuels and chemicals. Characteristics such as moisture content, carbohydrate, lignin, ash compositions, bulk density, and particle size/shape distributions impact conversion processes like fermentation, hydrothermal liquefaction, pyrolysis, and co-firing. Fermentation is well suited to handle high ash herbaceous materials with greater structural sugars content while processes like pyrolysis are 
well suited to utilize low ash and high lignin woody feedstocks. Optimizing biomass through selection of ideal cultivars, harvest time (spring vs. fall), and selective harvest methods will help reduce biomass variability and the overall load on the processing facilities. For instance, delaying biomass harvest until spring will reduce ash and moisture content, resulting in improved yields and efficiencies in thermochemical conversion processes and lessening slagging when cofiring biomass and coal. Mechanical, thermal, and chemical pretreatments, followed by densification, at local preprocessing supply depots may also be used to take advantage of biomass variability by separating out fractions that are naturally well suited to produce high-value products while transforming raw biomass feed streams into uniform-format commodities.

Acknowledgments This research was supported by the US DOE, Office of Energy Efficiency and Renewable Energy, BioEnergy Technologies Office, under DOE Idaho Operations Office Contract No. DE-AC07$05 \mathrm{ID} 14517$.

\section{Compliance with ethical standards}

Financial and competing interests disclosure The US Government retains and the publisher, by accepting the article for publication, acknowledges that the US Government retains a non-exclusive, paid-up, irrevocable, worldwide license to publish or reproduce the published form of this manuscript, or allow others to do so, for US Government purposes. The authors have no other relevant affiliations or financial involvement with any organization or entity with a financial interest in or financial conflict with the subject matter or materials discussed in the manuscript apart from those disclosed. No writing assistance was utilized in the production of this manuscript.

Open Access This article is distributed under the terms of the Creative Commons Attribution 4.0 International License (http:// creativecommons.org/licenses/by/4.0/), which permits unrestricted use, distribution, and reproduction in any medium, provided you give appropriate credit to the original author(s) and the source, provide a link to the Creative Commons license, and indicate if changes were made.

\section{References}

1. Perlack RD, Wright LL, Turhollow AF, Graham RL, Stokes BJ, Erbach DC (2005) Biomass as feedstock for a bioenergy and bioproducts industry: the technical feasibility of a billion-ton annual supply. DTIC Document. ORNL/TM-2005/66

2. Perlack RD, Eaton LM, Turhollow Jr AF, Langholtz MH, Brandt CC, Downing ME, Graham RL, Wright LL, Kavkewitz JM, Shamey AM (2011) US billion-ton update: biomass supply for a bioenergy and bioproducts industry. ORNL/TM-2011/224

3. Humbird D, Davis R, Tao L, Kinchin C, Hsu D, Aden A, Schoen P, Lukas J, Olthof B, Worley M (2011) Process design and economics for biochemical conversion of lignocellulosic biomass to ethanol. National Renewable Energy Laboratory Technical Report NREL. TP-5100-47764,

4. Poet-DSM (2013) POET and DSM to make advanced biofuels a reality by 2013 . http://poet-dsm.com/news/poet-and-dsm.aspx. Accessed 03/30/2015
5. Abengoa (2014) Abengoa celebrates grand opening of its first commercial-scale next generation biofuels plant. http://www. abengoa.com/web/en/noticias_y_publicaciones/noticias/historico/ 2014/10_octubre/abg_20141017.html. Accessed 03-11-2015

6. DuPont (2011) DuPont Industrial Biosciences announces new leader and name for cellulosic ethanol business. http://www2. dupont.com/BioFuel/en_US/whats_new/DuPont_Cellulosic_ Ethanol_111511.html. Accessed 03-11-2015

7. BETO (2014) Bioenergy Technologies Office Multi-Year Program Plan: November 2014 Update. http://www.energy.gov/eere/ bioenergy/downloads/bioenergy-technologies-office-multi-yearprogram-plan-november-2014-update. Accessed June 302015

8. Taylor S (2015) High Tonnage Forest Biomass Production Systems from Southern Pine Energy Plantations. http://www. energy.gov/eere/bioenergy/downloads/2015-peer-reviewpresentations-terrestrial-feedstocks. Accessed June 302015

9. Schmidt LD, Dauenhauer PJ (2007) Chemical engineering: hybrid routes to biofuels. Nature 447(7147):914-915

10. Sanderson K (2006) US biofuels: a field in ferment. Nature 444(7120):673-676

11. Ragauskas AJ, Williams CK, Davison BH, Britovsek G, Cairney J, Eckert CA, Frederick WJ Jr, Hallett JP, Leak DJ, Liotta CL, Mielenz JR, Murphy R, Templer R, Tschaplinski T (2006) The path forward for biofuels and biomaterials. Science 311(5760): 484-489. doi:10.1126/science.1114736

12. Huber GW, Iborra S, Corma A (2006) Synthesis of transportation fuels from biomass: chemistry, catalysts, and engineering. Chem Rev 106(9):4044-4098

13. Kenney KL, Smith WA, Gresham GL, Westover TL (2013) Understanding biomass feedstock variability. Biofuels 4(1):111-127

14. Tumuluru JS, Hess JR, Boardman RD, Wright CT, Westover TL (2012) Formulation, pretreatment, and densification options to improve biomass specifications for co-firing high percentages with coal. Ind Biotechnol 8(3):113-132. doi:10.1089/ind.2012.0004

15. Darr MJ, Shah A (2012) Biomass storage: an update on industrial solutions for baled biomass feedstocks. Biofuels 3(3):321-332. doi: $10.4155 /$ bfs. 12.23

16. Brownell HH, Yu EKC, Saddler JN (1986) Steam-explosion pretreatment of wood: effect of chip size, acid, moisture content and pressure drop. Biotechnol Bioeng 28(6):792-801. doi:10.1002/ bit.260280604

17. Akhtar J, Amin NAS (2011) A review on process conditions for optimum bio-oil yield in hydrothermal liquefaction of biomass. Renew Sust Energ Rev 15(3):1615-1624. doi:10.1016/j.rser. 2010.11.054

18. Peterson AA, Vogel F, Lachance RP, Fröling M, Antal JMJ, Tester JW (2008) Thermochemical biofuel production in hydrothermal media: a review of sub- and supercritical water technologies. Energy Environ Sci 1(1):32. doi:10.1039/b810100k

19. Bridgwater A, Meier D, Radlein D (1999) An overview of fast pyrolysis of biomass. Org Geochem 30(12):1479-1493

20. Carpenter D, Westover TL, Czernik S, Jablonski W (2014) Biomass feedstocks for renewable fuel production: a review of the impacts of feedstock and pretreatment on the yield and product distribution of fast pyrolysis bio-oils and vapors. Green Chem 16(2):384. doi:10.1039/c3gc41631c

21. Jenkins B, Baxter L, Miles T Jr, Miles T (1998) Combustion properties of biomass. Fuel Process Technol 54(1):17-46

22. Demirbas A (2004) Combustion characteristics of different biomass fuels. Prog Energy Combust Sci 30(2):219-230. doi:10. 1016/j.pecs.2003.10.004

23. Dibble CJ, Shatova TA, Jorgenson JL, Stickel JJ (2011) Particle morphology characterization and manipulation in biomass slurries and the effect on rheological properties and enzymatic conversion. Biotechnol Prog 27(6):1751-1759. doi:10.1002/btpr.669 
24. Van Walsum GP, Allen S, Spencer M, Laser M, Antal M Jr, Lynd L (1996) Conversion of lignocellulosics pretreated with liquid hot water to ethanol. In: Wyman C, Davison B (eds) Seventeenth Symposium on Biotechnology for Fuels and Chemicals, vol 57/ 58. Humana Press, ABAB Symposium, pp 157-170. doi:10.1007/ 978-1-4612-0223-3 14

25. Lynd LR (1996) Overview and evaluation of fuel ethanol from cellulosic biomass: technology, economics, the environment, and policy. Annu Rev Energy Environ 21(1):403-465

26. Kiran Sree N, Sridhar M, Venkateswar Rao L, Pandey A (1999) Ethanol production in solid substrate fermentation using thermotolerant yeast. Process Biochem 34(2):115-119

27. Elliott DC, Biller P, Ross AB, Schmidt AJ, Jones SB (2015) Hydrothermal liquefaction of biomass: developments from batch to continuous process. Bioresour Technol 178C:147-156. doi:10. 1016/j.biortech.2014.09.132

28. Jazrawi C, Biller P, Ross AB, Montoya A, Maschmeyer T, Haynes BS (2013) Pilot plant testing of continuous hydrothermal liquefaction of microalgae. Algal Res 2(3):268-277. doi:10.1016/j.algal. 2013.04.006

29. Zhang B, von Keitz M, Valentas K (2009) Thermochemical liquefaction of high-diversity grassland perennials. J Anal Appl Pyrolysis 84(1):18-24. doi:10.1016/j.jaap.2008.09.005

30. Demirbas A (2004) Effects of temperature and particle size on biochar yield from pyrolysis of agricultural residues. J Anal Appl Pyrolysis 72(2):243-248. doi:10.1016/j.jaap.2004.07.003

31. Spliethoff H, Hein K (1998) Effect of co-combustion of biomass on emissions in pulverized fuel furnaces. Fuel Process Technol 54(1):189-205

32. Reza MT, Emerson R, Uddin MH, Gresham G, Coronella CJ (2014) Ash reduction of corn stover by mild hydrothermal preprocessing. Biomass Convers Biorefinery. doi:10.1007/s13399-0140122-X

33. Lacey JA, Aston JE, Westover TL, Cherry RS, Thompson DN (2015) Removal of introduced inorganic content from chipped forest residues via air classification. Fuel 160:265-273

34. Weiss ND, Farmer JD, Schell DJ (2010) Impact of corn stover composition on hemicellulose conversion during dilute acid pretreatment and enzymatic cellulose digestibility of the pretreated solids. Bioresour Technol 101(2):674-678. doi:10.1016/j. biortech.2009.08.082

35. Toor SS, Rosendahl L, Rudolf A (2011) Hydrothermal liquefaction of biomass: a review of subcritical water technologies. Energy 36(5):2328-2342. doi:10.1016/j.energy.2011.03.013

36. Fahmi R, Bridgwater AV, Donnison I, Yates N, Jones JM (2008) The effect of lignin and inorganic species in biomass on pyrolysis oil yields, quality and stability. Fuel 87(7):1230-1240. doi:10. 1016/j.fuel.2007.07.026

37. Jenkins BM, Bakker RR, Wei JB (1996) On the properties of washed straw. Biomass and Bioenergy 10 (4):177-200. doi: http://dx.doi.org/10.1016/0961-9534(95)00058-5

38. Klinke HB, Thomsen AB, Ahring BK (2004) Inhibition of ethanol-producing yeast and bacteria by degradation products produced during pre-treatment of biomass. Appl Microbiol Biotechnol 66(1):10-26. doi:10.1007/s00253-004-1642-2

39. Palmqvist E, Hahn-Hägerdal B (2000) Fermentation of lignocellulosic hydrolysates. I: inhibition and detoxification. Bioresour Technol 74(1):17-24. doi:10.1016/S0960-8524(99)00160-1

40. Onwudili JA, Nahil MA, Wu C, Williams PT (2014) High temperature pyrolysis of solid products obtained from rapid hydrothermal pre-processing of pinewood sawdust. RSC Ad 4(66): 34784. doi:10.1039/c4ra04761c

41. Sun Y, Cheng J (2002) Hydrolysis of lignocellulosic materials for ethanol production: a review. Bioresour Technol 83(1):1-11

42. Bhaskar T, Sera A, Muto A, Sakata Y (2008) Hydrothermal upgrading of wood biomass: influence of the addition of
K2CO3 and cellulose/lignin ratio. Fuel 87(10-11):2236-2242. doi:10.1016/j.fuel.2007.10.018

43. Kirubakaran V, Sivaramakrishnan V, Nalini R, Sekar T, Premalatha M, Subramanian P (2009) A review on gasification of biomass. Renew Sust Energ Rev 13(1):179-186. doi:10.1016/ j.rser.2007.07.001

44. Mani S, Tabil LG, Sokhansanj S (2004) Grinding performance and physical properties of wheat and barley straws, corn stover and switchgrass. Biomass Bioenergy 27(4):339-352. doi:10. 1016/j.biombioe.2004.03.007

45. Adapa P, Tabil L, Schoenau G (2011) Grinding performance and physical properties of non-treated and steam exploded barley, canola, oat and wheat straw. Biomass Bioenergy 35(1):549-561. doi:10.1016/j.biombioe.2010.10.004

46. Vassilev SV, Baxter D, Andersen LK, Vassileva CG (2010) An overview of the chemical composition of biomass. Fuel 89(5): 913-933. doi:10.1016/j.fuel.2009.10.022

47. Vassilev SV, Baxter D, Andersen LK, Vassileva CG (2013) An overview of the composition and application of biomass ash. Part 1. Phase-mineral and chemical composition and classification. Fuel 105:40-76. doi:10.1016/j.fuel.2012.09.041

48. Vassilev SV, Baxter D, Andersen LK, Vassileva CG, Morgan TJ (2012) An overview of the organic and inorganic phase composition of biomass. Fuel 94:1-33. doi:10.1016/j.fuel.2011.09.030

49. Tao G, Lestander TA, Geladi P, Xiong S (2012) Biomass properties in association with plant species and assortments I: a synthesis based on literature data of energy properties. Renew Sust Energ Rev 16(5):3481-3506. doi:10.1016/j.rser.2012.02.039

50. Emerson R, Hoover A, Ray A, Lacey J, Cortez M, Payne C, Karlen D, Birrell S, Laird D, Kallenbach R, Egenolf J, Sousek M, Voigt T (2014) Drought effects on composition and yield for corn stover, mixed grasses, and Miscanthusas bioenergy feedstocks. Biofuels 5(3):275-291. doi:10.1080/17597269.2014.913904

51. Graham R, Liu W, Downing M, Noon C, Daly M, Moore A (1997) The effect of location and facility demand on the marginal cost of delivered wood chips from energy crops: a case study of the state of Tennessee. Biomass Bioenergy 13(3):117-123

52. Graham RL, English BC, Noon CE (2000) A geographic information system-based modeling system for evaluating the cost of delivered energy crop feedstock. Biomass Bioenergy 18(4):309-329

53. ASTM D3172-13, Standard Practice for Proximate Analysis of Coal and Coke, ASTM International, West Conshohocken, PA, 2013, www.astm.org

54. ASTM E870-82(2006), Standard Test Methods for Analysis of Wood Fuels, ASTM International, West Conshohocken, PA, 2006, www.astm.org

55. Hames BR, Thomas SR, Sluiter AD, Roth CJ, Templeton DW (2003) Rapid biomass analysis. In: Biotechnology for Fuels and Chemicals. Springer, pp 5-16

56. Templeton DW, Sluiter AD, Hayward TK, Hames BR, Thomas SR (2009) Assessing corn stover composition and sources of variability via NIRS. Cellulose 16(4):621-639. doi:10.1007/s10570009-9325-X

57. Sluiter A, Hames B, Ruiz R, Scarlata C, Sluiter J, Templeton D, Crocker D (2008) Determination of structural carbohydrates and lignin in biomass. Laboratory analytical procedure

58. Templeton DW, Scarlata CJ, Sluiter JB, Wolfrum EJ (2010) Compositional analysis of lignocellulosic feedstocks. 2. Method uncertainties. J Agric Food Chem 58(16):9054-9062. doi:10. 1021/jf100807b

59. Paulsen AD, Hough BR, Williams CL, Teixeira AR, Schwartz DT, Pfaendtner J, Dauenhauer PJ (2014) Fast pyrolysis of wood for biofuels: spatiotemporally resolved diffuse reflectance in situ spectroscopy of particles. ChemSusChem. doi:10.1002/cssc. 201301056 
60. INL (2015) DOE Biomass Feedstock Library. bioenergy.inl.gov. Accessed 3-10-2015

61. Gresham G, Emerson R, Hoover A, Miller A, Bauer W, Kenney K (2013) Evolution and development of effective feedstock specifications. Idaho National Laboratory (INL) INL/EXT-14-31510

62. Towler GP, Oroskar AR, Smith SE (2004) Development of a sustainable liquid fuels infrastructure based on biomass. Environ Prog 23(4):334-341. doi:10.1002/ep.10052

63. Adler PR, Sanderson MA, Weimer PJ, Vogel KP (2009) Plant species composition and biofuel yields of conservation grasslands. Ecol Appl 19(8):2202-2209

64. Duguid KB, Montross MD, Radtke CW, Crofcheck CL, Shearer SA, Hoskinson RL (2007) Screening for sugar and ethanol processing characteristics from anatomical fractions of wheat stover. Biomass Bioenergy 31(8):585-592. doi:10.1016/j.biombioe. 2007.03.002

65. Duguid KB, Montross MD, Radtke CW, Crofcheck CL, Wendt LM, Shearer SA (2009) Effect of anatomical fractionation on the enzymatic hydrolysis of acid and alkaline pretreated corn stover. Bioresour Technol 100(21):5189-5195. doi:10.1016/j.biortech.2009.03.082

66. Wyman CE, Goodman BJ (1993) Biotechnology for production of fuels, chemicals, and materials from biomass. Appl Biochem Biotechnol 39(1):41-59

67. Dale BE, Allen MS, Laser M, Lynd LR (2009) Protein feeds coproduction in biomass conversion to fuels and chemicals. Biofuels Bioprod Biorefin 3(2):219-230

68. Lemus R, Brummer EC, Moore KJ, Molstad NE, Burras CL, Barker MF (2002) Biomass yield and quality of 20 switchgrass populations in southern Iowa, USA. Biomass Bioenergy 23(6): 433-442

69. Eisenbies MH, Volk TA, Posselius J, Shi S, Patel A (2014) Quality and variability of commercial-scale short rotation willow biomass harvested using a single-pass cut-and-chip forage harvester. BioEnergy Res. doi:10.1007/s12155-014-9540-7

70. Mostajeran A, Rahimi-Eichi V (2009) Effects of drought stress on growth and yield of rice (Oryza sativa L.) cultivars and accumulation of proline and soluble sugars in sheath and blades of their different ages leaves. Am-Eurasian J Agric Environ Sci 5:264272

71. Keyvan S (2010) The effects of drought stress on yield, relative water content, proline, soluble carbohydrates and chlorophyll of bread wheat cultivars. J Anim Plant Sci 8:1051-1060

72. Mitchell PJ, O'Grady AP, Tissue DT, White DA, Ottenschlaeger ML, Pinkard EA (2013) Drought response strategies define the relative contributions of hydraulic dysfunction and carbohydrate depletion during tree mortality. The New phytol 197(3):862-872. doi:10.1111/nph.12064

73. Martinez JP, Lutts S, Schanck A, Bajji M, Kinet JM (2004) Is osmotic adjustment required for water stress resistance in the Mediterranean shrub Atriplex halimus L? J Plant Physiol 161(9): 1041-1051. doi:10.1016/j.jplph.2003.12.009

74. Pordesimo LO, Hames BR, Sokhansanj S, Edens WC (2005) Variation in corn stover composition and energy content with crop maturity. Biomass Bioenergy 28(4):366-374. doi:10.1016/j. biombioe.2004.09.003

75. Adler PR, Sanderson MA, Boateng AA, Weimer PJ, Jung H-JG (2006) Biomass yield and biofuel quality of switchgrass harvested in fall or spring. Agron J 98(6):1518. doi:10.2134/agronj2005. 0351

76. Lewandowski I, Clifton-Brown J, Andersson B, Basch G, Christian D, Jørgensen U, Jones M, Riche A, Schwarz K-U, Tayebi K (2003) Environment and harvest time affects the combustion qualities of genotypes. Agron J 95(5):1274-1280

77. Lewandowski I, Heinz A (2003) Delayed harvest of miscanthusinfluences on biomass quantity and quality and environmental impacts of energy production. Eur J Agron 19(1):45-63
78. Florine SE, Moore KJ, Fales SL, White TA, Lee Burras C (2006) Yield and composition of herbaceous biomass harvested from naturalized grassland in southern Iowa. Biomass Bioenergy 30(6): 522-528. doi:10.1016/j.biombioe.2005.12.007

79. Jungers JM, Fargione JE, Sheaffer CC, Wyse DL, Lehman C (2013) Energy potential of biomass from conservation grasslands in Minnesota, USA. PLoS One 8(4):e61209. doi:10.1371/journal. pone.0061209

80. Bonner IJ, Smith WA, Einerson JJ, Kenney KL (2014) Impact of harvest equipment on ash variability of baled corn stover biomass for bioenergy. BioEnergy Res 7(3):845-855

81. Alvira P, Tomas-Pejo E, Ballesteros M, Negro MJ (2010) Pretreatment technologies for an efficient bioethanol production process based on enzymatic hydrolysis: a review. Bioresour Technol 101(13):4851-4861. doi:10.1016/j.biortech.2009.11.093

82. Lin Y, Tanaka S (2006) Ethanol fermentation from biomass resources: current state and prospects. Appl Microbiol Biotechnol 69(6):627-642. doi:10.1007/s00253-005-0229-x

83. Bothast RJ, Schlicher MA (2005) Biotechnological processes for conversion of corn into ethanol. Appl Microbiol Biotechnol 67(1): 19-25. doi:10.1007/s00253-004-1819-8

84. Balat M (2011) Production of bioethanol from lignocellulosic materials via the biochemical pathway: a review. Energy Convers Manag 52(2):858-875. doi:10.1016/j.enconman.2010.08.013

85. Wyman CE (1994) Ethanol from lignocellulosic biomass: technology, economics, and opportunities. Bioresour Technol 50(1):3-15

86. Ruth MF, Thomas SR The effect of corn stover composition on ethanol process economics. In: 25th Symposium on Biotechnology for Fuels and Chemicals, 2003. Humana Press Breckenridge, CO

87. McKendry P (2002) Energy production from biomass (part 1): overview of biomass. Bioresour Technol 83(1):37-46. doi:10. 1016/S0960-8524(01)00118-3

88. Montross MD, Crofcheck CL (2004) Effect of stover fraction and storage method on glucose production during enzymatic hydrolysis. Bioresour Technol 92(3):269-274. doi:10.1016/j.biortech. 2003.09.007

89. Kang S, Li X, Fan J, Chang J (2013) Hydrothermal conversion of lignin: a review. Renew Sust Energ Rev 27:546-558. doi:10.1016/ j.rser.2013.07.013

90. Luterbacher JS, Tester JW, Walker LP (2012) Two-temperature stage biphasic $\mathrm{CO} 2-\mathrm{H} 2 \mathrm{O}$ pretreatment of lignocellulosic biomass at high solid loadings. Biotechnol Bioeng 109(6):1499-1507. doi: 10.1002/bit.24417

91. Williams CL, Chang C-C, Do P, Nikbin N, Caratzoulas S, Vlachos DG, Lobo RF, Fan W, Dauenhauer PJ (2012) Cycloaddition of biomass-derived furans for catalytic production of renewable pxylene. ACS Catal 2(6):935-939. doi:10.1021/cs300011a

92. Carlson TR, Vispute TP, Huber GW (2008) Green gasoline by catalytic fast pyrolysis of solid biomass derived compounds. ChemSusChem 1(5):397-400. doi:10.1002/cssc.200800018

93. Czernik S, Bridgwater AV (2004) Overview of applications of biomass fast pyrolysis oil. Energy Fuel 18(2):590-598. doi:10. 1021/ef034067u

94. Bridgwater A, Peacocke G (2000) Fast pyrolysis processes for biomass. Renew Sust Energ Rev 4(1):1-73

95. Bridgwater AV (2012) Review of fast pyrolysis of biomass and product upgrading. Biomass Bioenergy 38:68-94. doi:10.1016/j. biombioe.2011.01.048

96. Bridgwater A (1999) Principles and practice of biomass fast pyrolysis processes for liquids. J Anal Appl Pyrolysis 51(1):3-22

97. Zhang Q, Chang J, Wang T, Xu Y (2007) Review of biomass pyrolysis oil properties and upgrading research. Energy Convers Manag 48(1):87-92. doi:10.1016/j.enconman.2006.05.010

98. Mohan D, Pittman CU, Steele PH (2006) Pyrolysis of wood/ biomass for bio-oil: a critical review. Energy Fuel 20(3):848889. doi:10.1021/ef0502397 
99. Davidsson K, Pettersson J, Nilsson R (2002) Fertiliser influence on alkali release during straw pyrolysis. Fuel 81(3):259-262

100. Howe DT, Westover T, Carpenter DL, Santosa D, Emerson R, Deutch S, Starace A, Kutnyakov I, Lukins C (2015) Field-tofuel performance testing of lignocellulosic feedstocks: an integrated study of the fast pyrolysis/hydrotreating pathway. Energy \& Fuels

101. Andreae MO (1991) Biomass burning: its history, use, and distribution and its impact on environmental quality and global climate. Global biomass burning: Atmospheric, climatic and biospheric implications:3-21

102. Saidur R, Abdelaziz EA, Demirbas A, Hossain MS, Mekhilef S (2011) A review on biomass as a fuel for boilers. Renew Sust Energ Rev 15(5):2262-2289. doi:10.1016/j.rser.2011.02.015

103. Demirbas A (2005) Potential applications of renewable energy sources, biomass combustion problems in boiler power systems and combustion related environmental issues. Prog Energy Combust Sci 31(2):171-192. doi:10.1016/j.pecs.2005.02.002

104. Tumuluru JS, Sokhansanj S, Hess JR, Wright CT, Boardman RD (2011) REVIEW: a review on biomass torrefaction process and product properties for energy applications. Ind Biotechnol 7(5): 384-401

105. Tumuluru JS, Wright CT, Hess JR, Kenney KL (2011) A review of biomass densification systems to develop uniform feedstock commodities for bioenergy application. Biofuels Bioprod Biorefin 5(6):683-707. doi:10.1002/bbb.324

106. Ragland K, Aerts D, Baker A (1991) Properties of wood for combustion analysis. Bioresour Technol 37(2):161-168

107. Veijonen K, Vainikka P, Järvinen T, Alakangas E (2003) Biomass co-firing-an efficient way to reduce greenhouse gas emissions. VTT Processes, March 28:A1

108. Li C, Tanjore D, He W, Wong J, Gardner JL, Sale KL, Simmons BA, Singh S (2013) Scale-up and evaluation of high solid ionic liquid pretreatment and enzymatic hydrolysis of switchgrass. Biotechnol for biofuels 6(1):1-14

109. Cateto C, Hu G, Ragauskas A (2011) Enzymatic hydrolysis of organosolv Kanlow switchgrass and its impact on cellulose crystallinity and degree of polymerization. Energy Environ Sci 4(4): 1516. doi: $10.1039 / \mathrm{c} 0 \mathrm{ee} 00827 \mathrm{c}$

110. Wang G, Pan X, Zhu J, Gleisner R, Rockwood D (2009) Sulfite pretreatment to overcome recalcitrance of lignocellulose (SPORL) for robust enzymatic saccharification of hardwoods. Biotechnol Prog 25(4):1086-1093
111. Zhu J, Pan X, Wang G, Gleisner R (2009) Sulfite pretreatment (SPORL) for robust enzymatic saccharification of spruce and red pine. Bioresour Technol 100(8):2411-2418

112. Mosier N, Wyman C, Dale B, Elander R, Lee YY, Holtzapple M, Ladisch M (2005) Features of promising technologies for pretreatment of lignocellulosic biomass. Bioresour Technol 96(6):673686. doi:10.1016/j.biortech.2004.06.025

113. Chundawat SP, Venkatesh B, Dale BE (2007) Effect of particle size based separation of milled corn stover on AFEX pretreatment and enzymatic digestibility. Biotechnol Bioeng 96(2):219-231. doi:10.1002/bit.21132

114. Ray AE, Hoover AN, Nagle N, Chen X, Gresham GL (2013) Effect of pelleting on the recalcitrance and bioconversion of dilute-acid pretreated corn stover under low-and high-solids conditions. Biofuels 4(3):271-284

115. Kumar L, Tooyserkani Z, Sokhansanj S, Saddler JN (2012) Does densification influence the steam pretreatment and enzymatic hydrolysis of softwoods to sugars? Bioresour Technol 121:190-198

116. Hess JR, Wright CT, Kenney KL (2007) Cellulosic biomass feedstocks and logistics for ethanol production. Biofuels Bioprod Biorefin 1(3):181-190. doi:10.1002/bbb.26

117. McLaughlin SB, Adams Kszos L (2005) Development of switchgrass (Panicum virgatum) as a bioenergy feedstock in the United States. Biomass Bioenergy 28(6):515-535. doi:10.1016/j. biombioe.2004.05.006

118. Eranki PL, Bals BD, Dale BE (2011) Advanced Regional Biomass Processing Depots: a key to the logistical challenges of the cellulosic biofuel industry. Biofuels Bioprod Biorefin 5(6):621-630. doi:10.1002/bbb.318

119. Hess JR, Wright CT, Kenney KL, Searcy EM (2009) Uniformformat solid feedstock supply system: a commodity-scale design to produce an infrastructure-compatible bulk solid from lignocellulosic biomass - executive summary. Idaho National Laboratory (INL) INL/EXT-09-15423

120. Thompson DN, Campbell T, Bals B, Runge T, Teymouri F, Ovard LP (2013) Chemical preconversion: application of low-severity pretreatment chemistries for commoditization of lignocellulosic feedstock. Biofuels 4(3):323-340

121. Yang B, Wyman CE (2008) Pretreatment: the key to unlocking low-cost cellulosic ethanol. Biofuels Bioprod Biorefin 2(1):26-40. doi:10.1002/bbb.49 